\title{
Jan Grzegorzewski w końcowych latach życia: 1916-1922
}

\author{
Jan Tyszkiewicz \\ Uniwersytet Warszawski, Wydział Historyczny / \\ Akademia Humanistyczna w Pułtusku, Wydział Historyczny
}

Jan Grzegorzewski at the End of Life: the Years 1916-1922

Summary: Jan Grzegorzewski (c. 1846-1922) was a journalist and researcher. He studied Slavonic philology in Odessa. From 1870 he lived in Lviv, Istanbul, Bulgaria, Krakow and in Zakopane. He was director of the Hyacinteum Institute in Sofia (1904-1915) and spent the last years of his life (1916-1922) in Poland. He explored Highland and Spisz folklore and published popular and scientific articles. After being awarded a grant from the Mianowski Fund, he together with orientalists A. Gawroński W. Kotwicz and J. Rozwadowski began publishing an academic periodical called the Oriental Yearbook (vol. 1, 1914-1918). He was a co-founder of the Polish Society of Oriental Studies (1922) and published a number of papers on Polish-Turkish relations in the seventeenth and eighteenth centuries. He devoted the years 1920-1922 to studying the culture and language of the Karaites in Halicz. We have managed to collect a great deal of material that had remained in the hands of skilled Karaites from Halicz. The documents left by J. Grzegorzewski and preserved in Lviv and Halicz were later examined by T. Kowalski (1934). They are of high academic value.

Keywords: Jan Grzegorzewski, turkology, journalism, Oriental Yearbook, Karaim's culture 
Urodził się w Szulejkach na Wołyniu, w niezamożnej rodzinie polskiej. Nie wiadomo dokładnie kiedy, ok. 1846-1850 roku. Po ukończeniu gimnazjum w Żytomierzu, studiował slawistykę w Uniwersytecie Odesskim. Tam nauczył się języka bułgarskiego i albańskiego. Reprezentował typ indywidualisty i oryginała z epoki późnego romantyzmu. Strojem i zachowaniem przypominał emisariusza sprawy narodowej, typowego dla poprzedniego pokolenia z 3 ćwierćwiecza XIX stulecia. Zbierał materiały o kulturze ludów słowiańskich i innych, na Półwyspie Bałkańskim i w Karpatach. Jego publikacje miały charakter reportaży podróżnika i publicysty. Podejmując różne tematy, apelował, informował i inspirował. Wykazywał dużą ruchliwość i aktywność. Żył samotnie. Poza podróżami po Europie, o których mówił, ale czego zweryfikować nie można, ostatnie parolecie związał z Lwowem, Krakowem, Zakopanem i Haliczem. Brakuje dotąd orientalisty, który zechciałby napisać o Janie Grzegorzewskim monografię1.

Materiały po J. Grzegorzewskim, korespondencja, rękopisy, zbiory, osobista biblioteka i wiadomości o niej, nie zostały dostatecznie opracowane. Zostały rozproszone i częściowo zaginęły.

A. Najstarsze materiały przekazane zostały do Biblioteki Ossolineum (prywatna biblioteka, może także rękopisy i monety) w depozyt 1904-1905. W większości zaginęły podczas walk polsko-ukraińskich we Lwowie w 1918. Mogło coś ocaleć, jeżeli J. Grzegorzewski, po powrocie z Sofii coś odebrał i wziął do domu.

B. Część mniej ważnych papierów i korespondencji pozostała w Sofii. Ambitne i z pozoru nierealne plany założenia Polskiej Stacji Naukowej na Wschodzie w Sofii (w planach była też stacja w Konstantynopolu) zw. Hyacynthaeum, udały się. J. Grzegorzewski z własnych funduszy i dorywczo uzyskiwanych dotacji potrafił utrzymać się, pisać i podjąć próby publikacji naukowych w 1. 1906-1914². Wbrew przeciwnościom pewna część jego spuścizny rękopiśmiennej z Sofii ocalała. W latach 70. XX w. ostatnia pozostałość dokumentacji po Hyacynthaeum sprowadzona została do Polski, dzięki staraniom Józefa Sulimowicza,

1 (A. Gawroński), Jan Grzegorzewski, „Rocznik Orientalistyczny”, t. I, cz.2, 1919-1924, Lwów 1925, s. 332-334; W. Zajączkowski, Jan Grzegorzewski (ok. 1850-1922), [w:] Polski Slownik Biograficzny, t. 9, 1960, s. 95-97. Zmarł 17 XI 1922. Monografię o Grzegorzewskim zamierzał napisać Juliusz Zborowski, kustosz Muzeum Tatrzańskiego.

2 J. Grzegorzewski, Działalność Polaków na Bałkanie i na dalszym Wschodzie, Polska w kulturze powszechnej, red. F. Koneczny, cz. 1, Kraków 1918, s. 188; J. Grzegorzewski, Grób Warneńczyka, Kraków 1911; J. Grzegorzewski, Z sidżyllatów rumelijskich epoki wyprawy wiedeńskiej. Acta tureckie, Lwów 1912. Por.: J. Reychman, O wykorzystanie źródeł orientalnych do dziejów Polski, „Przegląd Historyczny”, t. 58, 1967, nr 2, s. 295-300. 
ucznia Ananiasza Zajączkowskiego ${ }^{3}$. Materiały sofijskie są substancją warsztatową m.in. po pisaniu artykułów do Rocznika Orientalistycznego.

C. Najobfitsze materiały pochodzą przede wszystkim z 1916-1922. Zostawione przez J. Grzegorzewskiego we Lwowie w 1922. Przed śmiercią zapisane zostały w testamencie Instytutowi Orientalistycznemu Uniwersytetu im. Jana Kazimierza. Procedura spadkowa na rzecz Uniwersytetu Lwowskiego trwała w sądzie kilka lat, zapewne do 1926. Uczestniczyli w niej A. Gawroński i Z. Smogorzewski.

D. Niewielka część materiałów, brudnopisów i notatek, głównie z 1920-1922, ale nie wykluczone, że także z 1900-1903, pozostała w Haliczu. Podarowana została przez J. Grzegorzewskiego rodzinom Karaimów, z którymi się przyjaźnił. W ten sposób cząstka spuścizny trafiła do zbioru Józefa Sulimowicza (obecnie u córki Anny).

Teoretycznie materiały po jego działalności organizacyjnej, publicystycznej i czasopiśmienniczej mogły też pozostać w Zakopanem, jednakże nie wiedzą o tym niczego znawcy dziejów miasta Z. Radwańska-Paryska i W.H. Paryski. J. Grzegorzewski mieszkał w Zakopanem i przyjeżdżał tam wielokrotnie w latach 1883-1919. Zakładał tutaj czasopisma, projektował wydawanie naukowego Rocznika Zakopiańskiego i otworzenie regionalnego Muzeum Zakopiańskiego ${ }^{4}$. Szansa na odnalezienie wykazu przekazanych książek i rękopisów do Ossolineum w 1904-1905 czy Instytutu Orientalistycznego we Lwowie po 1922 jest obecnie nikła. Nie wiadomo czy zachowała się, poza uniwersytetem lwowskim Jana Kazimierza, dokumentacja procesu spadkowego. Istnieje ewentualność, że mogły tam znajdować się jakieś spisy czy wykazy jednostek rękopiśmiennych. Dla pożytku nauki byłoby dobrze wyjaśnić, czy wszystko ze Lwowa zostało po 1944 przewiezione do Krakowa. Materiały po Janie Grzegorzewskim są obecnie przechowywane w Bibliotece PAN i Archiwum Nauki Polskiej w Krakowie. Są to zapewne materiały udostępnione ok. 1932-1933 T. Kowalskiemu oraz

3 O spuściźnie po J. Grzegorzewskim, odzyskiwanej z Sofii, mało precyzyjnie: J. Reychman, Peleryna, ciupaga i znak tajemny, Kraków 1976, s. 104. Resztki materiałów sofijskich dołączone zostały do zbioru J. Sulimowicza.

4 Z. Radwańska-Paryska, W.H. Paryski, Wielka Encyklopedia Tatrzańska, Poronin 1995, hasła: Grzegorzewski Jan (pseud. Ewan i in.) (1846 lub 1849-1922), s. 382-383; Almanach Tatrzański, s. 25-26; Goniec Tatrzański, s. 346; J. Zborowski, Z dziejów ruchu wydawniczego w Zakopanem do roku 1899, „Rocznik Podhalański”, t. 3, 1985, s. 56-73. 
przewiezione po II wojnie światowej. Dopiero specjalna kwerenda może ustalić czy jest to wszystko z daru pośmiertnego Grzegorzewskiego. 5 .

Zainteresowanie budziły materiały karaimskie. Na polecenie prof. Władysława Kotwicza asystent Instytutu Orientalistycznego we Lwowie dr Eugeniusz Słuszkiewicz wyodrębnił notatki i papiery odnoszące się do problematyki karaimskiej. Przekazal je do Krakowa - „abym je mógł swobodnie przejrzeć i wykorzystać”, jak napisał T. Kowalski. „Scheda (obejmowała) kilka skrzynek książek różnorodnej treści i wartości, nieco monet zebranych na Wschodzie i w kraju; sporą stertę szpargałów, zapisanych jego trudno czytelnym pismem"6. Ocenę dostępnych mu materiałów T. Kowalski opublikował. Wątpliwe, aby zapoznał się wówczas z materiałami pozostającymi w Haliczu. Materiały J. Sulimowicza, obecnie w Warszawie, są odrębnej proweniencji. Były w większości gromadzone na miejscu badań. Są pozostałością jego pobytów w Haliczu ok. 1900-1903 i w latach 1920-1922.

W ostatnich latach życia J. Grzegorzewski podejmował różne nowe inicjatywy i powracał do starych. Dawne memoriały zabiegające o rozwijanie studiów orientalistycznych w Warszawie, Krakowie i Lwowie nie odniosły skutku. Ale w początku 1914 roku uzyskał on z Kasy im. Mianowskiego fundusze na rozpoczęcie wydawania Rocznika Orientalistycznego w Krakowie. Ten naukowy periodyk miał stać się centralnym organem wszystkich orientalistów polskich. Grzegorzewski postanowił przerwać działalność Hyacynthaeum i wrócić do Polski. Jeszcze w Sofii napisał rozprawę dotyczącą zjawisk językowych w tzw. Kodeksie kumańskim (czerwiec 1914). Ze względów organizacyjnych i finansowych pierwszy tom Rocznika ukazał się w dwóch częściach: cz. 1 za lata 1914-1915 (Kraków 1915, s. 1-224) i cz. 2 za lata 1916-1918 (Kraków 1918, s. 225-355).

W obu częściach redakcję tworzyli: Andrzej Gawroński (Kraków), Jan Grzegorzewski (Sofia), Władysław Kotwicz (Petersburg) i Jan Rozwadowski (Kraków). W 1918 Grzegorzewski był już we Lwowie, Kotwicz jeszcze w Petersburgu, a do redakcji włączono Tadeusza Kowalskiego. Wydanie pierwszego tomu Rocznika Orientalistycznego - ,jest wyłączną zasługą Jana Grzegorzewskiego. On dał inicjatywę i On się o fundusze wystaral" - stwierdził w nekrologu dobrze zorientowany A. Gawroński. W części 2 tomu 1 Grzegorzewski zamieścił 2 rozprawy: o narzeczu łucko-halickim Karaimów i dwóch XVIII-wiecznych

5 Zob.: M. Kizilov, Jan Grzegorzewski's Karaite materials in the archive of the Polish Academy of Science in Kraków, „Karaite Archives”, t. 1, 2013, s. 64-76.

6 T. Kowalski, Materiały karaimskie śp. Jana Grzegorzewskiego, „Myśl Karaimska”, z. 10, 1934, s. 19. 
fermanach sułtańskich dotyczących handlu z Polską. Niewątpliwie wszystkie 3 artykuły otrzymały niezbędną aprobatę jego utytułowanych kolegów z redakcji . Opublikowany Rocznik znacznie wyprzedzał powołanie Polskiego Towarzystwa Orientalistycznego. Statut PTO zatwierdzony został we Lwowie w maju 1922, jeszcze za życia J. Grzegorzewskiego. Pierwszy Zarząd Główny został wybrany przez Walne Zgromadzenie dopiero w lipcu 1923, przeszło pół roku po zgonie J. Grzegorzewskiego. Założenie Rocznika skonsolidowało całe środowisko orientalistów rozproszonych po różnych miastach; znacznie przyspieszyło dalszy jego rozwój. Wkład w to dzieło J. Grzegorzewskiego okazał się nieoceniony.

W 1918-1920 J. Grzegorzewski nadal zabiegał o podjęcie bezpośrednich kontaktów handlowych Polski z krajami Bliskiego Wschodu. O realizację tych zamierzeń starał się bezskutecznie w Warszawie ok. 1890 (projekt szkoły handlowej) i we Lwowie w 1904, pisząc List otwarty do J.E.J.W. Pana Marszałka Krajowego $w$ sprawie orientalizmu i orientalistyki. Do realizacji zamierzenia niezbędna była nauka języków wschodnich w Polsce. Działalność gospodarcza miała wspierać rozwój orientalistyki. Dlatego w 1918 J. Grzegorzewski opublikował syntetyczny artykuł pt. „Działalność Polaków na Bałkanie i na dalszym Wschodzie”, obejmujący okres od XIII do pocz. XX wieku. Podkreślał w nim zasługi i osiągnięcia Polaków, podróżników i misjonarzy ${ }^{8}$.

Po przyjeździe z Sofii do kraju J. Grzegorzewski zaczął znowu jeździć do Zakopanego. Powrócił do propagowania tzw. prądu tatrzańskiego (vel idei tatrzaństwa), swoistego regionalizmu góralsko-tatrzańskiego. W kultywowaniu tatrzaństwa powinni jego zdaniem uczestniczyć literaci, publicyści, twórcy nauki i kultury polskiej. Wszyscy razem będą w stanie stworzyć nurt odrodzenia ogólnonarodowego. Grzegorzewski był również podatny na inne oryginalne koncepcje, popularne w środowisku inteligencji galicyjskiej (prawspólnota i dziedzictwo po Ariach itp.). Materiały z uprzednich dziesięcioleci (zbierane od ok. 1880) pozwoliły mu opracować ostatecznie szkic pt. Na Spiszu.

7 J. Grzegorzewski, Dzetacyzm perski „kodeksu kumańskiego”, „Rocznik Orientalistyczny”, t. 1, cz. 1, za 1914-1915, Kraków 1915, s. 87-93; tegoż, Caraimica. Jezyk Łach-Karaimów. Narzecze południowe (lucko-halickie), „Rocznik Orientalistyczny”, t. 1, cz. 2, za 1916-1918, s. 252-296 oraz tegoż, Turcica. Dwa fermany sultańskie z w. XVIII-tego. Zarys historyczny traktatów handlowych Polski z Turcja, „Rocznik Orientalistyczny”, t. 1, cz. 2, za 1916-1918, s. 297-333. W tomie 1 prace J. Grzegorzewskiego zajęły blisko 90 stron, na wszystkich 355. Por.: K. Dobosz, Poczatki i pierwszy tom „Rocznika Orientalistycznego”. Przyczynek do dziejów czasopisma, „LingVaria”, t. 7, 2012/2 (14), s. 177-193.

8 J. Grzegorzewski, Działalność Polaków na Bałkanie i na dalszym Wschodzie, [w:] Polska w kulturze powszechnej, red. F. Koneczny, cz. 1 (Część ogólna), s. 167-188. 
Studia i teksty folklorystyczne (Lwów 1919). Wykorzystywał on opowieści i pieśni zebrane na całym Spiszu, jeszcze przed jego podziałem na część polską i czechosłowacką. Od 1903 parokrotnie odmawiano mu druku tej pracy ze względu na promowanie w niej fantastycznej teorii. Na Podhalu i Spiszu odnajdował on rzekomo praaryjski kult dualistyczny, dobra i zła ${ }^{9}$. Druga praca dotycząca tego terenu - Gwary spiskie - pozostała w rękopisie i zaginęła.

Walka zbrojna i działania dyplomatyczne prowadzące do formowania się niepodległego państwa polskiego wciągnęły Grzegorzewskiego w krąg dyskusji politycznej. W broszurce Ku Czarnomorzu. Zarys baltycko-czarnomorskiej dynamiki ludów (Kraków 1919) próbował dostarczyć argumentacji naukowej za włączeniem części ziem Ukrainy do terytorium Polski. Hipotezy naukowe - językowe, etnograficzne i historyczne - użyte zostały jako argumenty geopolityczne. Autor nie byl jednak dostatecznie przygotowany do tego rodzaju rozważań, pomimo trzydziestu lat obracania się w środowisku naukowym Krakowa i Lwowa. Jego teoria dynamiki ludów, wypieranie ku północy Lechitów przez Rusinów i koczowników, była słuszna częściowo i tylko dla IX-XII w. Broszura była reakcją autora na walkę o Lwów z Zachodnioukraińską Republiką Ludową w 1918-1919. Formułując tekst o etnicznych dziejach Międzymorza włączył się on w ówczesne dyskusje o Polsce jako państwie federacyjnym ${ }^{10}$.

Na lata powojenne 1918-1921 przypadło też jego zainteresowanie emigrantami z Kaukazu, przybyłymi do Polski, zwłaszcza do Lwowa. Został tutaj współzałożycielem Towarzystwa Przyjaźni Polsko-Ormiańskiej. Powodowały nim różne względy; zrozumienie dla położenia wygnańców, skłonności podróżnicze i problemy naukowo-językowe. Ormianie posługiwali się narzeczem języka kipczackiego, bliskiego językowi Karaimów. W języku ormiańsko-kipczackim była prowadzona dokumentacja ormiańskiej gminy we Lwowie do XVII w. ${ }^{11}$. Wiedza w tym zakresie była Grzegorzewskiemu potrzebna. Zajęty innymi sprawami nie

9 J. Zborowski, Historia pewnej ksiażki. Wspomnienie o Janie Grzegorzewskim, „Rocznik Podhalański”, t. 5, 1992, s. 75-80; szersze tło sprawy: J. Reychman, Peleryna, passim.

10 J. Tyszkiewicz, Przedmowa i uwagi krytyczne, [w:] J. Grzegorzewski, Ku Czarnomorzu, wyd. II, Gdańsk 1996, s. 5-18. Zob. A. Weryha-Darowski, Kresy ruskie Rzeczypospolitej i Województwa: kijowskie, wołyńskie, brasławskie i podolskie, Warszawa 1919; P. Okulewicz, Koncepcja międzymorza $w$ myśli i praktyce polskiej obozu Józefa Piłsudskiego w latach 1918-1926, Poznań 2001 i in.

11 E. Tryjarski, Zapisy sądu duchownego Ormian miasta Lwowa za lata 1625-1630 w jezyku ormiańsko-kipczackim, Kraków 2010, PAN Rozprawy Wydziału Historyczno-Filozoficznego, t. 111; rec.: J. Tyszkiewicz, Nowe źródło do dziejów Ormian we Lwowie w początku XVII w., „Przegląd Orientalistyczny”, 2012, nr 1-2, s. 96-101. 
napisał wówczas żadnego artykułu o Ormianach. Wziął jednak udział w serii odczytów, organizowanych w lwowskim Kole Literackim, w końcu 1919. W dn. 30 XII 1919 wygłosił obszerną prelekcję, której tekst opublikowano dziesięć lat później we lwowskiej Gazecie Porannej. Traktowała ona o dawnych związkach odległej Armenii z Polską ${ }^{12}$.

Zapewne w marcu 1920 dotarł do J. Grzegorzewskiego list pisany 20 II 1920, od znajomego Tatara z Ałuszty na Krymie. Zaufani przekazywali ten list z rąk do rąk, zupełnie nieoficjalnie. Tekst listu pisany był po turecku, z literą "M” zamiast podpisu. Trwała zacięta wojna domowa w Rosji centralnej i na Półwyspie Krymskim. Piszący oficer, zainteresowany niepodległością Krymu pytał Grzegorzewskiego o polityczne i wojskowe plany dowództwa polskiego. Na poprzedni list - z lipca 1919 - Grzegorzewski nie odpisał; zapewne go nie otrzymał. Z formy tekstu można wnosić, że znajomość między nimi była dawna i zażyła; prawdopodobnie z okresu pobytu w Sofii. Wojskowy z Ałuszty był pewnie jednym z korespondentów J. Grzegorzewskiego z czasów sofijskiego Hyacynthaeum $^{13}$. Dla uzyskania pełnej orientacji o zamierzeniach Józefa Piłsudskiego, do Warszawy przyjechał jesienią Dżafer Sejdamet Kyrymer (28 X 6 XI 1920), gdzie odbył wiele rozmów politycznych m. in. z Marszałkiem.

Dwa ostatnie lata życia spędził J. Grzegorzewski na badaniach kultury i języka Karaimów, mieszkając wśród nich w Haliczu. W 1920-1922 badacz intensywnie zbierał materiał leksykalny do słownika języka Karaimów halickich. W sprawozdaniu, z przeglądu pozostałych po Grzegorzewskim „materiałów karaimskich”, z tego ostatniego okresu, Tadeusz Kowalski napisał: (J. Grzegorzewski) "cieszył się, że słownik osiąga kilka tysięcy wyrazów. Gromadził materiały do gramatyki karaimskiej. Notował wszystko co dotyczyło historii, religii, literatury i etnografii Karaimów halickich"14. Dlatego swoją spuścizną chciał zainteresować orientalistów we Lwowie. T. Kowalski krytycznie oceniał dokonania Grzegorzewskiego, ponieważ ten nie robił systematycznej i naukowej dokumentacji dla zbieranych: wyrażeń, powiedzeń czy poszczególnych słów.

Notatki do słownika składały się z dwóch zbiorów: obszernego (1129 fiszek) z przeszło 10 tys. różnych zapisów i mniejszego (kilkaset kartek) uporządkowanego

12 J. Grzegorzewski, Polska - Armenia - Wschód, „Gazeta Poranna”, Lwów 1929, nr. 6, $8,10,13,15,19$ i 20 . Tekst odczytu drukowano w odcinkach.

13 J. Tyszkiewicz, Nadzieje Tatarów krymskich na pomoc Polski: luty 1920, „Rocznik Tatarów Polskich”, t. 1, 1993, s. 71-74; tutaj tekst listu i próba rekonstrukcji okoliczności towarzyszących.

14 T. Kowalski, Materiały karaimskie, s. 19. 
alfabetycznie, sporządzonego na pożółkłym papierze. Drugi zbór mógł być starszy i związany z pisaniem w 1903 artykułu o dialekcie halickim języka karaimskiego, opublikowanego po niemiecku w Wiedniu. „Materiał w stanie zupełnie surowym, niepewny i nieułożony”, stanowiący najważniejszą część spuścizny z pobytu w Haliczu, ocenił T. Kowalski - zbyt pospiesznie - jako „bezużyteczny”15. Dla Kowalskiego, który nie znał sposobów działania ani bliżej źródeł zbieranych informacji, materiał miał jedynie orientacyjne znaczenie, jako pochodzący z Halicza. Już w następnych zdaniach T. Kowalski podziwia pracowitość i drobiazgowość zapisów. Brak odpowiedniego przygotowania językoznawczego osłabiał przede wszystkim wartość wywodów etymologicznych. Wszystko inne - było i nadal stanowi - cenną dokumentację źródłową. Badania Kowalskiego w Haliczu, późniejsze o kilkanaście lat, nie mogły już korzystać z pamięci i wiedzy najstarszych informatorów Grzegorzewskiego.

Prócz zapisków słownikowych po J. Grzegorzewskim pozostały: notatki dotyczące gramatyki (teka: Caraitica. Materiały do gramatyki języka karaimskiego), plik - „właściwości mowy potocznej”, notatki ogólne z różnych opracowań językoznawczych, ważny zespół dokumentów dotyczących życia gminy karaimskiej w Haliczu, zagadki (3), opowiadania (4), 2 poematy Zachariasza Abrahamowicza (zm. 1903) i poemat Jakuba Józefa Leonowicza, wyjątki z modlitewników oraz pakiet zapisów różnych. W tym ostatnim znajdowały się utrwalone wiadomości dotyczące: literatury, języka, etnografii i historii Karaimów z Halicza.

Ostateczna konkluzja z przeglądu tej schedy wypadła pod piórem T. Kowalskiego pozytywnie. Materiały te posiadają dużą wartość naukową. „Należy je traktować z szacunkiem, jako pamiątkę po zasłużonym badaczu i człowieku idei, który w ciężkich warunkach, w znoju i niedostatku, pokonując trudności, jakie mu stawiał brak należytego przygotowania naukowego, dążył wytrwale do celu...tj. wskrzeszenia orientalistyki polskiej i do związania jej z zagadnieniami rodzimemi”16. A. Gawroński w nekrologu oraz T. Kowalski w artykule o pozostawionych materiałach, zgodnie stwierdzili, że Janowi Grzegorzewskiemu należy się duża wdzięczność za podjęte starania i ich rezultaty „uwieńczone nie jednym trwałym wynikiem”.

Pobyt w małym miasteczku nad Dniestrem nie przeszkadzał Grzegorzewskiemu w śledzeniu ważnych wydarzeń politycznych kształtujących Polskę. 8 I 1922 miały odbyć się wybory do Sejmu Litwy Środkowej w Wilnie. Kilka dni wcześniej zarząd gminy karaimskiej sformułował odezwę do Karaimów w Trokach i Wilnie, przypominając o ich więzach z innymi gminami (Eupatoria, Łuck, Halicz). „Wyrażamy nadzieję - brzmiał tekst odezwy - że wy w nadchodzącym plebiscycie

15 T. Kowalski, Materialy karaimskie, s.21.

16 T. Kowalski, Materialy karaimskie, s.28. 
w Litwie Środkowej głosować będziecie na rzecz prawowitego przyłączenia tego kraju do całości Rzeczypospolitej Polskiej, która od wieków otaczała i teraz otacza opieką macierzyńską. My tutaj zresztą nie przestajemy żywić wiary że... państwo Litewskie wejdzie w ścisłe przymierze lub unię z Rzeczypospolitą Polską, jak to dawniej bywało". Odezwę przesłano 2 I 1922 telegrafem do Wilna. Zachęta czy współudział w tej akcji Grzegorzewskiego są wysoce prawdopodobne. To on w lwowskim czasopiśmie Wiek Nowy z 13 I 1922 opublikował treść tego apelu, informując przy tej okazji o dziejach i położeniu Karaimów w Haliczu' ${ }^{17}$.

$\mathrm{Na}$ zakończenie wolno stwierdzić, że obaj profesorowie uniwersyteccy A. Gawroński i T. Kowalski - dystansowali się od wielu osobliwych wywodów J. Grzegorzewskiego, jednocześnie żywiąc wobec niego wdzięczność za jego dziesięciolecia pracy na rzecz kultury polskiej i zorganizowanie edycji naukowego Rocznika Orientalistycznego. Przy wszystkich zastrzeżeniach, uczeni profesorowie przyznali J. Grzegorzewskiemu zasługi naukowe, przede wszystkim włączenia do obiegu nieznanych dotąd i ulegających zapomnieniu źródeł pisanych oraz źródeł wywołanych, żywych tradycji ustnych utrwalonych w ostatnim momencie. Dzielny publicysta i romantyczny orientalista dożył realizacji swoich głównych celów życiowych: niepodległej Polski, założenia Polskiego Towarzystwa Orientalistycznego i naukowego periodyku polskiego „Rocznika Orientalistycznego”. Statut PTO został zatwierdzony przez władze wojewódzkie we Lwowie w maju 1922. Projekt statutu złożyli: Jan Czekanowski, Andrzej Gawroński i Zygmunt Smogorzewski. W owych latach Jan Czekanowski był przede wszystkim uznanym badaczem Afryki, jej kultury, języków i etnosów ${ }^{18}$; antropologia dopiero zaczynała być jego domeną. Schorowany J. Grzegorzewski mógł - pośrednio, przez bliski kontakt z A. Gawrońskim, uczestniczyć także w układaniu tego statutu.

\section{Bibliografia}

[Gawroński, A.], Jan Grzegorzewski, Rocznik Orientalistyczny, t. 1, cz. 2, 1919-1924, [1925], s. 332-336.

Dobosz, K., Początki i pierwszy tom „Rocznika Orientalistycznego”. Przyczynek do dziejów czasopisma, Ling Varia, t. 7, 2012/2 (14), s. 177-193.

Grzegorzewski J., Działalność Polaków na Bałkanie i na dalszym Wschodzie. Polska w kulturze powszechnej, red. F. Koneczny, cz. 1, Kraków 1918.

17 J. Grzegorzewski, Karaimi haliccy a plebiscyt litewski, „Wiek Nowy”, nr 6185, 13 I 1922, s. 5 .

18 J. Tyszkiewicz, W Europie i Afryce: Jan Czekanowski przed 1914, [w:] Polska. Europa. Afryka. Studia ofiarowane prof. B. Nowakowi, red. M. Dygo, A. Koseski, Pułtusk 2007, s. 395-404. 
Grzegorzewski J., Z sidżyllatów rumelijskich epoki wyprawy wiedeńskiej. Acta tureckie, Lwów 1912.

Grzegorzewski, J., Caraimica. Jezyk Łach-Karaimów. Narzecze południowe (łucko-halickie), Rocznik Orientalistyczny, t. 1, cz. 2, 1916-1918, s. 252-296.

Grzegorzewski, J., Dzetacyzm perski „kodeksu kumańskiego”, Rocznik Orientalistyczny, t. 1, cz. 1, 1914-1915 [1915], s. 85-93.

Grzegorzewski, J., Grób Warneńczyka, Kraków 1911.

Grzegorzewski, J., Polska - Armenia - Wschód, Gazeta Poranna, Lwów, nr 6, 8, 10, 13, 15, 19, 20, 1929.

Grzegorzewski, J., Turica. Dwa fermany sultańskie $z$ w. XVIII-tego. Zarys historyczny traktatów handlowych Polski z Turcja, Rocznik Orientalistyczny, t. 1, cz. 2, 1916-1918, s. 297-333.

Grzegorzewski. J., Karaimi haliccy a plebiscyt litewski, Wiek Nowy, nr 6185, 13 I 1922, s. 5. Kizilov, M., Jan Grzegorzewski's Karaite materials in the archive of the Polish Academy of Science in Kraków, Karaite Archives, t. 1, 2013, s. 59-84.

Kowalski, T., Materiały karaimskie śp. Jana Grzegorzewskiego, Myśl Karaimska, z. 10, 1934, s. 19-28.

Okulewicz, P., Koncepcja międzymorza $w$ myśli i praktyce polskiej obozu Józefa Piłsudskiego w latach 1918-1926, Poznań 2001.

Radwańska-Paryska, Z., Paryski, W.H., Wielka Encyklopedia Tatrzańska, Poronin 1995, hasła: Grzegorzewski Jan (pseud. Ewan i in.) (1846 lub 1849-1922), s. 382-383; Almanach Tatrzański, s. 25-26; Goniec Tatrzański, s. 346.

Reychman J., O wykorzystanie źródeł orientalnych do dziejów Polski, Przegląd Historyczny, t. 58, nr 2, 1967, s. 295-300.

Reychman, J., Peleryna, ciupaga i znak tajemny, Kraków 1976.

Tryjarski, E., Zapisy sadu duchownego Ormian miasta Lwowa za lata 1625-1630 w języku ormiańsko-kipczackim, Kraków 2010 (= Rozprawy Wydziału Historyczno-Filozoficznego PAN, nr 111).

Tyszkiewicz, J., Nadzieje Tatarów krymskich na pomoc Polski: luty 1920, Rocznik Tatarów Polskich, t. 1, 1993, s. 71-74.

Tyszkiewicz, J., Nowe źródło do dziejów Ormian we Lwowie w początku XVII w., Przegląd Orientalistyczny, z. 1-2, 2012, s. 96-101.

Tyszkiewicz, J., Przedmowa i uwagi krytyczne, [w:] J. Grzegorzewski, Ku Czarnomorzu, wyd. II, Gdańsk 1996, s. 5-18.

Tyszkiewicz, J., W Europie i Afryce: Jan Czekanowski przed 1914, [w:] Polska. Europa. Afryka. Studia ofiarowane prof. B. Nowakowi, red. M. Dygo, A. Koseski, Pułtusk 2007, s. 395-404. Weryha-Darowski, A., Kresy ruskie Rzeczypospolitej i Województwa: kijowskie, wołyńskie, brasławskie i podolskie, Warszawa 1919.

Zajączkowski, W., Jan Grzegorzewski (ok. 1850-1922), Polski Słownik Biograficzny, t. 9, 1960, s. 95-97.

Zborowski, J., Historia pewnej ksiązi. Wspomnienie o Janie Grzegorzewskim, Rocznik Podhalański, t. 5, 1992, s. 75-80 [szersze tło sprawy: J. Reychman, Peleryna, passim]. Zborowski, J., Z dziejów ruchu wydawniczego w Zakopanem do roku 1899, Rocznik Podhalański, t. 3, 1985, s. 56-73. 